\title{
Evaluation of Support Program for Young Entrepreneurs: Evidence from Georgia
}

\author{
Lasha Zivzivadze1, Tengiz Taktakishvili', Ekaterine Zviadadze², Giorgi Machavariani1 \\ ${ }^{1}$ Georgian National University SEU, Tbilisi, Georgia \\ ${ }^{2}$ Ivane Javakhishvili Tbilisi State University, Tbilisi, Georgia \\ Email:.zivzivadze@yahoo.com, t.taktakishvili@seu.edu.ge, ekaterine74@yahoo.com,g.machavariani@seu.edu.ge
}

How to cite this paper: Zivzivadze, L., Taktakishvili, T., Zviadadze, E., \& Machavariani, G. (2021). Evaluation of Support Program for Young Entrepreneurs: Evidence from Georgia. Open Journal of Business and Management, 9, 2977-2987. https://doi.org/10.4236/ojbm.2021.96166

Received: September 25, 2021

Accepted: November 20, 2021

Published: November 23, 2021

Copyright $\odot 2021$ by author(s) and Scientific Research Publishing Inc. This work is licensed under the Creative Commons Attribution International License (CC BY 4.0).

http://creativecommons.org/licenses/by/4.0/ (c) $\underset{\mathrm{By}}{\mathrm{Br}}$ Open Access

\begin{abstract}
The paper provides an analysis of the impact of state program aimed at promoting entrepreneurial activities of youth in Georgia. The program named "Young Entrepreneur" was established to provide necessary funds for the young people in order to help them in overcoming one of the major obstacles they face when trying to start own business, that is lack of finances. Because of the greater attention to the program and its funding from the budget it is important to study how successful the program was and how properly the taxpayers' money was spent. The hypothesis of the research states that the program was successful and met the expectations and results pre-defined by its authors. Paper introduces the program, its objectives and components and provides relevant data analysis to show an impact of the program. Study employs the data taken from the Ministry of Environmental Protection and Agriculture of Georgia. The program financed total 241 beneficiaries. For evaluation of the program 5 criteria are used: relevance, effectiveness, efficiency, impact and sustainability. Analysis given in the paper indicates that the program was successful. The annual indicators were fully achieved compared to the planned indicators. Furthermore, the program was implemented efficiently with the low budget expenditure. Finally, based on the evaluation and analysis, specific recommendations are provided. As there are no previous scientific or policy evaluations of the program, the paper is a first attempt to analyse the results of the "Young Entrepreneur".
\end{abstract}

\section{Keywords}

Young Entrepreneur, Funding, Rural Investments, Program Evaluation, Impact Analysis

\section{Introduction}

The Georgian agricultural sector faces several challenges, including absence of 
modern technologies, smallholder farmers, low productivity, lack of education, high unemployment rate etc. The unemployment rate in rural areas is one of the most considerable challenges for Georgia. Specifically, it is an issue for young people. According to the National Statistics Office of Georgia, in 2020 the unemployment rate was considerably higher for the age group of 20 to $40 \mathrm{com}$ pared to the age group of 40 to 64 .

To overcome the unemployment challenge in the country, specifically for the young people, certain steps have been recently taken by the Ministry of Environmental Protection and Agriculture of Georgia (hereafter MEPA). Since 2012, the Government of Georgia announced the agriculture sector as a top priority and launched several projects/programs, including the program "Young Entrepreneur", which started in 2018. The program was financed by the Danish International Development Agency (DANIDA) and was implemented by the Nonentrepreneurial Non-commercial Legal Entity (NNLE) Rural Development Agency, which is functioning under the MEPA. The key objectives of this program are: development of young entrepreneurs and their involvement into businesses; enhance the economic development and strengthen the private sector and create the new jobs in rural areas.

An entrepreneur who is registered according to the Georgian Law and is from the 18 to 35 years old for men and from the 18 to 40 years old for women can submit an application to the NNLE Rural Development Agency. The program "Young Entrepreneur" has three pillars: 1) Technical assistance prior to receiving of the co-financing; 2) Co-financing-financial assistance; 3) Technical assistance after receiving the co-financing. Under the program, agricultural and non-agricultural activities are financed. NNLE Rural Development Agency makes up $40 \%$ of co-financing from the total investment and the rest is financed by the beneficiary.

The primary objective of the presented paper is to evaluate the program "Young Entrepreneur" initiated and implemented by the MEPA. This is the first attempt to evaluate the program "Young Entrepreneur". Employment of youth and their involvement into entrepreneurial activities are among the key priorities of the Government of Georgia. This is the specific program, which should give opportunity and motivation for the young people to start the agricultural and nonagricultural business in rural areas.

The hypothesis of the study is that the program was a success and met the expectations and results pre-defined by its authors. Paper contributes to the research of state funded programs aiming at developing entrepreneurial activities and particularly those of young people. It is especially relevant for Georgia since there is a lack of new ventures and business projects initiated by youth. By scientific evaluation of the program policy makers will learn what the benefit of it was, what were the main drawbacks and what to consider while drawing the new programs for the similar purposes.

There is no other research aiming at evaluation of this program. Hence, paper 
provides initial results for discussion and will be valuable document for the policy makers and other stakeholders.

Paper is constructed as follows. In the second section, the literature review is presented. The methodology and data collection follows are provided by the separate part of the paper. Using the methodology, the key results and analysis are given as well as conclusions and specific recommendations.

\section{Literature Review}

Many authors (Holienka et al., 2016; Green, 2013; Ćoćkalo et al., 2017) have tried to find out what the major incentives are behind the youth entrepreneurial activities. Most of them agree that getting youth population involved in entrepreneurship will create huge value added to the country's economy. However, there are some considerations about the role of the government in this process and form of support to be provided to youth people in order to trigger their entrepreneurial attitudes.

Report of the United Nations (UN) offers the indicators to use for measurement of the programs supporting youth entrepreneurship. These indicators are compatible with the characteristics of relevance, availability, timeliness and comparability. Also, the authors suggest to use these indicators for analyzing 6 policy areas: overall indicators, optimization of the regulatory environment, development of entrepreneurial education and skills, promoting technology exchange and innovation, improving access to finance, supporting awareness and networking (UNCTAD, 2015).

Holienka, Pilková and Jancovicová (2016) found that the biggest drivers behind entrepreneurship are education and training of future entrepreneurs. Also, a proper networking is an important factor. In this light it is recommended for the government to take these factors into account while drawing a support policy for entrepreneurs (Holienka, Pilková, \& Jancovicová, 2016).

Green (2013) states that younger women are probably least likely to start their own business. The author did not find clear evidence that particular type of financial support improves entrepreneurial outcomes of youth. On the other hand, the author finds that debt even in a lower interest rate is a burden for young entrepreneurs and reduces their chances to successfully run the business, but the fact that the loan (hence risk) is shared and necessary finances provided, plays supportive role, on the other hand (Green, 2013).

The study provided by the European parliament (2015) finds that the programs initiated by the state that combines business incubation services and necessary finances trigger young people towards entrepreneurship (Study for the EMPL Committee, 2015).

Ćoćkalo, Đorđević, Nikolić, Stanisavljev and Terek (2017) found that as youth unemployment represents one of key economic problems government institutions must take steps to overcome it. Main aim here as authors conclude is to provide stimuli for young people to be involved in entrepreneurial process. Au- 
thors found insufficient financial resources as a main factor behind youth being reluctant to start their own business (Ćoćkalo, Đorđević, Nikolić, Stanisavljev, \& Terek, 2017). Providing necessary environment for young people to find impetus for entrepreneurship should be one of the main priorities according to the authors.

OECD uses relevance, effectiveness, efficiency, impact and sustainability criteria to assess The Entrepreneurship and Innovation Program. For this they developed the indicators in a way to contribute to the above mentioned five criteria. These criteria are widely used among OECD researches including the policy to support entrepreneurship. Hence, this approach can also be used in the given research with the high validity (Centre for Strategy and Evaluation Services, 2010).

Given these findings, we can conclude that entrepreneurial activities of youth population must be supported by the government, who should mainly focus on allocation of necessary funds to them, because young people lack financial resources and removing this barrier will make them involved in creating new ventures.

\section{Methodology and Data Collection}

To Evaluate the program "Young Entrepreneur" the following 5 criteria are used: relevance, effectiveness, efficiency, impact and sustainability (Evaluation Manual. UNIDO Independent Evaluation Division, 2018). The evaluation criteria and relevant questions are shown in the Table 1.

Table 1. Evaluation and relevant questions.

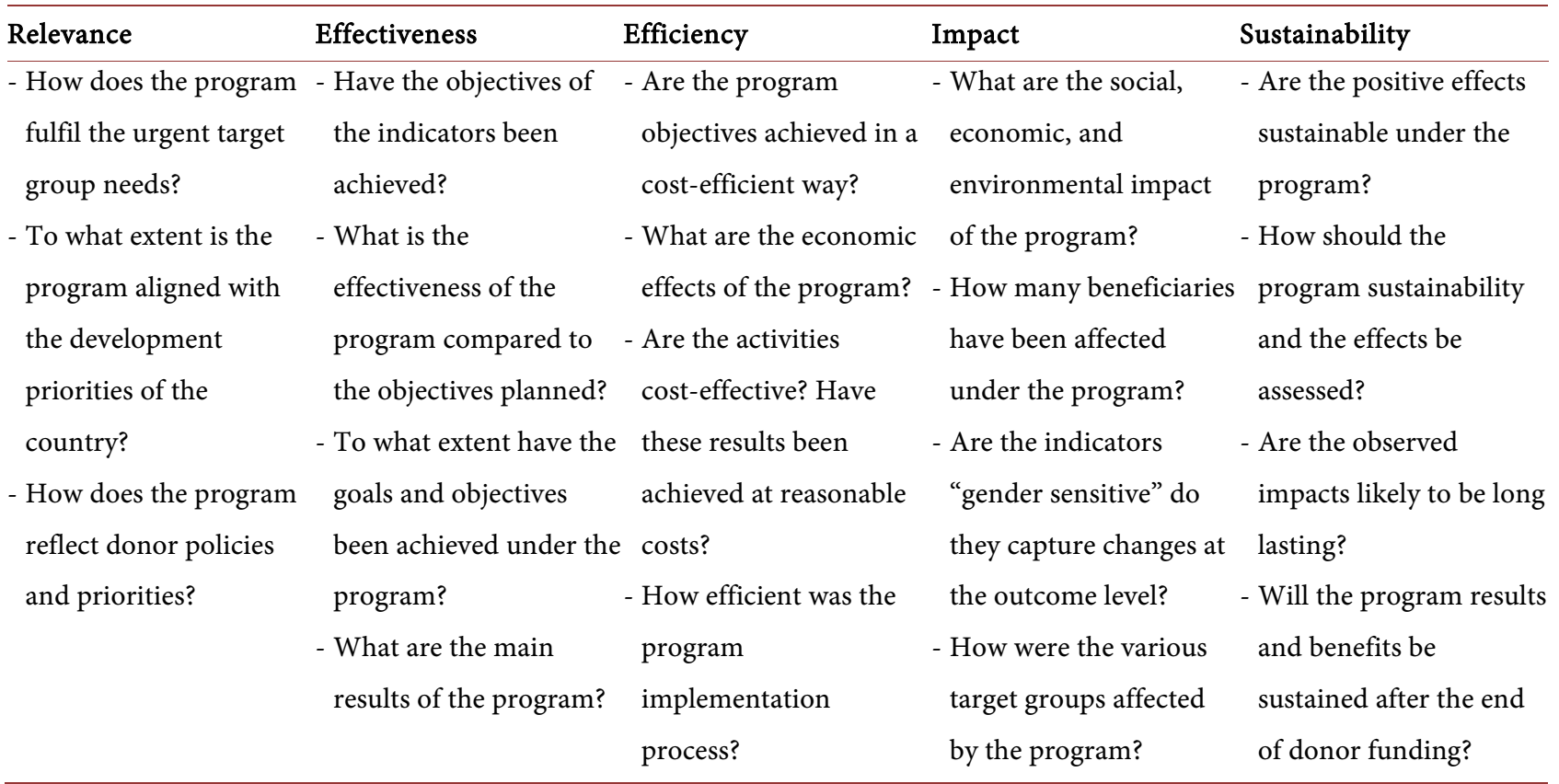

Source: Evaluation Manual UNIDO, 2018. 
For the program analysis, the following relevant strategic policy documents and data were considered: the Agricultural Development Strategy, the Rural Development Strategy and relevant action plans, the implementation of monitoring progress reports and also, the data provided by the NNLE Rural Development Agency.

The data about the program "Young Entrepreneur" are taken from the NNLE Rural Development Agency. The NNLE Rural Development Agency is the state organization which operates under the MEPA. The data covers the period of time from 2018 to 2021 . The sample size is defined as 241 beneficiaries which were financed under the program.

\section{Analysis and Key Results}

\section{1) Relevance}

At the national level, Georgia had two main policy documents elaborated and implemented in agricultural and rural development from the period of 2015 to 2020. In 2015, MEPA elaborated the sectoral policy document-Strategy for Agricultural Development for 2015-2020 and the relevant action plan. Moreover, in coordination of relevant ministries, the MEPA elaborated multisectoral policy document-the Rural Development Strategy for 2017-2020 and the relevant action plan. In these strategy action plans the activity/program "Young Entrepreneur" with the indicators and the budget expenditures are defined for implementation. Furthermore, at the global level, the program "Young Entrepreneur" has a tight connection with the Sustainable Development Goals (SDGs) including the SDG 2Zero Hunger, the SDG 4-Quality Education, the SDG 5-Gender Equality and the SDG 8-Decent Work and Economic Growth. So, the relevance of the program "Young Entrepreneur" is very high on both the national and the global level.

\section{2) Effectiveness}

The planned/target quantitative indicators of the program "Young Entrepreneur", which was reflected in the agricultural and rural development strategies, were fully achieved (Monitoring Reports for 2018, 2019 and 2020 on the Implementation of the 2015-2020 Agricultural Development Strategy 2018-2020 Action Plan of Georgia, 2019, 2020, 2021).

\section{3) Efficiency}

The planned indicators of the program "Young Entrepreneur", which was reflected in the agricultural and rural development strategies, were fully achieved. Besides, the planned indicators were achieved with low expenditure of the budget compare to the planned budget by years (see the Table 2 below) (Monitoring Reports for 2018, 2019 and 2020 on the Implementation of the 2017-2020 Rural Development Strategy 2018-2020 Action Plan of Georgia, 2019, 2020, 2021). In other words, it means that the program was efficiently implemented.

\section{4) Impact}

This program had the social and economic impacts. Social impact showed that within the period of 2018-2021, the total beneficiaries, which benefited from this program, were 241 young entrepreneurs. 
Table 2. Program "Young Entrepreneur" planned and actual indicators and budget.

\begin{tabular}{llll}
\hline & $\mathbf{2 0 1 8}$ & $\mathbf{2 0 1 9}$ & $\mathbf{2 0 2 0}$ \\
\hline Planned Indicators & $\begin{array}{l}\text { Financed 100 } \\
\text { beneficiaries }\end{array}$ & $\begin{array}{l}\text { Financed 100 } \\
\text { beneficiaries }\end{array}$ & $\begin{array}{l}\text { Financed 37 } \\
\text { beneficiaries }\end{array}$ \\
Actual Indicators & $\begin{array}{l}\text { Financed 114 } \\
\text { beneficiaries }\end{array}$ & $\begin{array}{l}\text { Financed 100 } \\
\text { beneficiaries }\end{array}$ & $\begin{array}{l}\text { Financed 39 } \\
\text { beneficiaries }\end{array}$ \\
Planned Budget & 3 million GEL & 6.2 million GEL & 3.3 million GEL \\
Actual Budget & 2.9 million GEL & 4 million GEL & 2 million GEL \\
\hline
\end{tabular}

Source: https://www.mepa.gov.ge/En/Reports/.

The economic impact implied that in 2018-2021, from the government, the young entrepreneurs totally received around 9.5 million GEL. It is noteworthy to show that the total investment, that the program generated, was estimated as 24.6 million GEL.

According to the NNLE Rural Development Agency data, around 63\% from the total young entrepreneurs were represented from Kakheti region. Reletively less active regions were Imereti and Adjara. Around 85\% of grants were distributed in agricultural sector and the rest $15 \%$ in non-agricultural sector, specifically in hotel industry. From the agricultural sector, the majority grants (more than $60 \%$ ) were distributed in primary agricultural production.

As it was mentioned above the program "Young Entrepreneurs" aimed to facilitate agriculture and rural related economic activities by providing financial resources to the farmers and entrepreneurs. The program was a 3 years project funded by state budget and implemented by the Ministry. The total budget of the program was approximately $9.5 \mathrm{mln}$ GEL. It is also relevant to mention that almost 50\% (around $4.5 \mathrm{mln}$ GEL) of the program's total fund was spent in 2018. Under the program $3.3 \mathrm{mln}$ GEL and $1.56 \mathrm{mln}$ GEL were paid out in 2019 and 2020 respectively (see the Table 3 below).

In spite of the fact that the total program budget was not large relatively to the total state budget of the country dedicated to the agriculture sector, it is considerable to underline that the program "Young Entrepreneur" was a countrywide one covering all regions of the country. Around 85\% (7.8 mln GEL) of the program funds were spent in Eastern Georgian regions such as Kakheti, Mtskheta-Mtianeti, Qvemo Kartli, Shida Kartli, and Samtskhe-Javakheti. The rest of the financial resources (approx. $1.5 \mathrm{mln}$ GEL) were supplied to the recipient entities from the Western Georgian regions. The highest share in the program budget had Kakheti region with 58\% (around $5.4 \mathrm{mln}$ GEL) (see the Table 4 below).

It is worth to discuss the structure of program funding; In terms of budget shares the viticulture had the highest portion in the total program fund among various agriculture related economic activities. Around $40 \%$ of the program's financial resources were pledged to wine-making subfield. The wine-making also had a significant portion in the program funds. Its share was around $24 \%$. 
Within the implementation of the program, $3.7 \mathrm{mln}$ GEL, $2.3 \mathrm{mln}$ GEL, $1.6 \mathrm{mln}$ GEL and $0.9 \mathrm{mln}$ GEL were contributed to the wine-making, viticulture, agritourism and livestock farming subareas respectively. It is also relevant to note that above mentioned sub-fields of agriculture reflect country's competitive and comparative advantages and priorities. Their shares in total program budget exceed $85 \%$. As for the rest activities, they include nut and hazelnut production, diary production, agriproduct storing, fishing, vegetable processing, and some other significant activities (see the Table 5 below).

According to the NNLE Rural Development Agency data, 61\% were the male beneficiaries and the rest $39 \%$ were the female beneficiaries in the period of 2018-2021.

Under the program, pre-finance support was given to the 1,429 participants. In other words, it means that to increase the awareness, the program team have the consultation in the country. The submitted application under this program was estimated around 1100. The total beneficiaries were 241. However, postfinance support was distributed to the 153 participants based on their needs. The training was conducted to the part of the beneficiaries because of beneficiary's needs.

5) Sustainability

Table 3. Program expenditures by years, thousand GEL.

\begin{tabular}{cccc}
\hline & $\underline{2018}$ & $\underline{2019}$ & $\underline{2020}$ \\
\hline Program co-financing & 4495 & 3344 & 1557 \\
Total investment & 11,663 & 8423 & 4137 \\
\hline
\end{tabular}

Source: MEPA.

Table 4. Program expenditures by regions (thousand GEL).

\begin{tabular}{cccccc}
\hline & Kakheti & Mtskheta-Mtianeti & Qvemo-Kartli & Racha-Lechkhumi & Shida Kartli \\
\hline Program co-financing & 5420 & 996 & 578 & 511 & 442 \\
Total investment & 13,932 & 2648 & 1575 & 1278 & 1142 \\
\hline & Samtkhe-Javakheti & Guria & Samegrelo-Zemo-Svaneti & Adjara AR & Imereti \\
\hline $\begin{array}{c}\text { Program co-financing } \\
\text { Total investment }\end{array}$ & 409 & 394 & 304 & 759 & 524 \\
\hline
\end{tabular}

Source: MEPA.

Table 5. Program expenditures by subfields (thousand GEL).

\begin{tabular}{cccccc}
\hline & Wine-making & Viticulture & Agritourism & Livestock Farming & Rest Activities \\
\hline Program co-financing & 3732 & 2274 & 1554 & 886 & 950 \\
Total investment & 9514 & 5961 & 3990 & 2380 & 2377 \\
\hline
\end{tabular}

Source: MEPA. 
The Government of Georgia established the program "Young Entrepreneur", with financial support of the Danish International Development Agency. The program created additional incentives for the young entrepreneurs in agricultural and nonagricultural sector to start the businesses and invest the private financial resources. According to the research survey conducted under the program, the average annual income of the selected beneficiaries in 2020 compared to 2018 increased by $80 \%$. Therefore, this means that more income gives more motivation and resources for the entrepreneurs to invest and expand their businesses in the future. In addition, there are other projects/programs (Preferential Agro-credit, Co-funding of Processing and Storage Facilities, Rural Development Program etc.) implemented by the NNLE Rural Development Agency, that can be additional opportunities for the program beneficiaries to take part and get supplementary financial resources. Therefore, the program beneficiaries in Georgia have other opportunities for making their businesses more sustainable in the long-run period.

\section{Conclusion}

The program "Young Entrepreneur" was the relevant program for Georgia. This program was reflected in both strategic documents: Agricultural Development Strategy for 2015-2020 and Rural Development Strategy for 2017-2020. Both policy documents are connected with global priorities-Sustainable Development Goals. Hence, the hypothesis stated by the authors is accepted. The actual results of the program even exceeded anticipated results.

According to the analysis, it can be concluded that the program implementation was effective. The annual indicators were fully achieved compared to the planned indicators. Furthermore, the program was implemented efficiently with the low budget expenditure.

The program started in 2018 and finished in 2021 and it had socio-economic impacts. In this period, the total beneficiaries, which benefited from the financial support, were 241 young entrepreneurs. Also, it can be concluded, that inclusion was one of the key challenges of this program, because the majority of beneficiaries were from the Kakheti region.

Unlike the project "Plant the Future" (Zivzivadze, Taktakishvili, Zviadadze, \& Machavariani, 2021), the program "Young Entrepreneur" was the gender equality supporting program, because according to the program rules a beneficiary can be from the 18 to 40 age group in case of female and from the 18 to 35 age range in case of male. So, the gender equality was supported under this program, and as a result $61 \%$ of beneficiaries were male, while only $39 \%$ of beneficiaries were female.

The program "Young Entrepreneur" generated around 25 million GEL in total public and private investment. As a grant, young entrepreneurs received around 10 million GEL from the government. In addition, under this program, 153 program participants out of 241 got educational support (64\%) via the training. 
It should be noted that under the program, the demands from the young entrepreneurs were higher (around 1100 submitted applications), however only around $22 \%$ were financed.

This program is sustainable because according to the study conducted in 2020, the selected beneficiaries increased the income by $80 \%$ on average. In addition, the program beneficiaries have an opportunity to participate in other projects implemented by the NNLE Rural Development Agency, which supports the program sustainability.

The limitation of the presented paper is that there is no prior research on the evaluation of the program "Young Entrepreneur". In addition, it should be noted that this paper does not offer research of program beneficiaries.

\section{Recommendations}

The government of Georgia should make more research-based decisions when deciding to fund programs like the "Young Entrepreneur". Namely, it should investigate more deeply the reasons behind success or failure of the funds it grants and based on this experience making new decisions about funding.

Programs supporting youth entrepreneurship should be more oriented towards creation of entrepreneurial ventures that use modern technologies in their operations. Efficiency, productivity and hence, competitive strength of modern enterprises rely on technologies, so if startups want to survive, they have also to be committed to using technologies in their businesses.

In order to make the program more successful, the information campaign should be more active. Many people still do not have relevant and/or comprehensive information about this program. They must be fully informed about the benefits of the program and the necessary procedures of participation. Furthermore, based on the results, inclusiveness is one of the challenges under this program. As we mentioned majority of beneficiaries were from Kakheti region. Hence, there should enhance the awareness concerning the program, which should positively affect on program inclusion.

Additional components can be added to the program including: training, consultations and so on. The analyzed literature suggests that there are several key factors determining youth involvement in the business and if all of them are taken into account the necessary environment, supporting entrepreneurial activities of youth will be created. As a result, after beneficiaries got financial resources only the part of them received the trainings. Another recommendation is that all granted beneficiaries of the program should be trained based on their needs.

As it is mentioned before the demands for this program from the young generation were very high, but because of the limited financial resources, most of applicants have not received the financial support from the program. One of the recommendations is to continue this program in the future in order to facilitate the young entrepreneurs and start-ups in the agriculture sector of the country. 
The last recommendation is related to the distribution of funds. In this regard, it was underlined before that under the program "Young Entrepreneur" more than $85 \%$ program's funds were spent in the Eastern regions of Georgia. Taking into consideration the fact that there was a high demand on participating in the program, we would recommend the government to allocate the financial resources more evenly among the regions to avoid increasing inequality in the country. It is relevant to highlight that another alternative is to narrow focus of the program by selecting only few regions/municipalities for implementation in order to avoid high administration costs.

\section{Conflicts of Interest}

The authors declare no conflicts of interest regarding the publication of this paper.

\section{References}

(2019). Monitoring Report for 2018 on the Implementation of the 2015-2020 Agricultural Development Strategy 2018-2020 Action Plan of Georgia.

https://mepa.gov.ge/En/Reports

(2019). Monitoring Report for 2018 on the Implementation of the 2017-2020 Rural Development Strategy 2018-2020 Action Plan of Georgia. https://mepa.gov.ge/En/Reports

(2020). Monitoring Report for 2019 on the Implementation of the 2015-2020 Agricultural Development Strategy 2018-2020 Action Plan of Georgia.

https://mepa.gov.ge/En/Reports

(2020). Monitoring Report for 2019 on the Implementation of the 2017-2020 Rural Development Strategy 2018-2020 Action Plan of Georgia. https://mepa.gov.ge/En/Reports

(2021). Monitoring Report for 2020 on the Implementation of the 2015-2020 Agricultural Development Strategy 2018-2020 Action Plan of Georgia. https://mepa.gov.ge/En/Reports

(2021). Monitoring Report for 2020 on the Implementation of the 2017-2020 Rural Development Strategy 2018-2020 Action Plan of Georgia. https://mepa.gov.ge/En/Reports

Centre for Strategy and Evaluation Services (2010). Evaluation of the Indicators of the Entrepreneurship and Innovation Programme. Final Report.

Ćoćkalo, D., Đorđević, D., Nikolić, M., Stanisavljev, S., \& Terek, E. (2017). Analysis of Possibilities for Improving Entrepreneurial Behaviour of Young People: Research Results in Central Banat District. Journal of Engineering Management and Competitiveness (JEMC), 7, 97-108. https://doi.org/10.5937/jemc1702097C

Green, F. (2013). Youth Entrepreneurship. A Background Paper for the OECD Centre for Entrepreneurship, SMEs and Local Development.

Holienka, M., Pilková, A., \& Jancovicová, Z. (2016). Youth Entrepreneurship in Visegrad Countries. Entrepreneurial Business and Economics Review, 4, 105-121. https://doi.org/10.15678/EBER.2016.040407

Study for the EMPL Committee (2015). The Availability and Use of Assistance for Entrepreneurship to Young People.

UNCTAD (2015). Policy Guide on Youth Entrepreneurship.

UNIDO Independent Evaluation Division (2018). Evaluation Manual. 
https://www.unido.org/sites/default/files/files/2018-04/Evaluation\%20Manual\%20e-bo ok.pdf

Zivzivadze, L., Taktakishvili, T., Zviadadze, E., \& Machavariani, G. (2021). An Evaluation of Permanent Crops: Evidence from the "Plant the Future" Project, Georgia. Open Agriculture, 6, 212-222. https://doi.org/10.1515/opag-2021-0012 